\title{
Analisis Kualitas Air dan Status Mutu Serta Beban Pencemaran Sungai Mahap di Kabupaten Sekadau Kalimantan Barat
}

\author{
Ranty Christiana $^{1^{*}}$, Ika Muthya Anggraini ${ }^{2}$, Hezliana Syahwanti ${ }^{3}$ \\ 1,2,3 Program Studi Teknik Sipil, Universitas Panca Bhakti, Pontianak \\ *Koresponden email: ranty_christiana@yahoo.co.id
}

Diterima: 30 Januari 2020

Disetujui: 13 Februari 2020

\begin{abstract}
Sungai Mahap is used by the people of Nanga Mahap Village, Nanga Mahap District, Sekadau Regency for daily needs such as cooking, transportation and even consumption as drinking water. Utilization is done by the community because this area has not been flooded with clean water facilities. The quality and status of the Mahap River water quality standard needs to be further examined to study the feasibility of water as an air source used by the community regarding the importance of increasing plantation activities upstream. This research uses descriptive method using quantitative. Air sampling was conducted using a sample survey method with proposed parameters namely BOD, COD, pH, DO, TSS and NH3. Water quality testing is based on Government Regulation No. 82 of 2001 and determines the status of water quality using the STORET method and the pollution index based on the Decree of the Minister of Environment No.115 of 2003. In this study, the river pollution load was also calculated. The results show that the composition of BOD, COD, and Fe has exceeded the specified quality standards. The water quality status of the Mahap River is classified as moderate to severe based on the STORET method and Pollution Index. The highest river pollution load occurs at point II, in the dry season at $104.725 \mathrm{~kg} /$ day and in the rainy season at $171.873 \mathrm{~kg} / \mathrm{day}$
\end{abstract}

Keywords: air quality, air quality status, STORET index, pollution index, Mahap River

\begin{abstract}
Abstrak
Sungai Mahap dimanfaatkan masyarakat Desa Nanga Mahap, Kecamatan Nanga Mahap, Kabupaten Sekadau untuk kebutuhan sehari-hari seperti aktivitas memasak, mencuci bahkan dikonsumsi sebagai air minum. Pemanfaatan ini dilakukan masyarakat karena wilayah tersebut belum teraliri fasilitas air bersih. Kualitas dan status mutu baku air Sungai Mahap perlu ditinjau lebih lanjut untuk mengetahui kelayakan air sebagai sumber air yang digunakan oleh masyarakat akibat pengaruh keberadaan aktivitas perkebunan di hulu sungai. Penelitian ini menggunakan metode deskriptif dengan pendekatan kuantitatif. Pengambilan sampel air dilakukan dengan sample survey method dengan parameter yang diuji yaitu BOD, COD, pH, DO, TSS dan $\mathrm{NH}_{3}$. Pengujian kualitas air berdasarkan Peraturan Pemerintah Nomor 82 Tahun 2001 dan penentuan status mutu air dengan metode STORET dan indeks pencemaran berdasarkan Keputusan Menteri Lingkungan Hidup No.115 Tahun 2003. Dalam penelitian ini dihitung juga beban pencemaran sungai. Hasil menunjukkan bahwa kandungan BOD, COD dan Fe telah melampaui baku mutu yang telah ditetapkan. Status Mutu air Sungai Mahap tergolong tercemar sedang hingga berat berdasarkan metode STORET dan Indeks Pencemaran. Beban pencemaran sungai tertinggi terjadi pada titik II, pada musim kemarau sebesar 104.725 $\mathrm{kg} / \mathrm{hari}$ dan pada musim hujan sebesar $171.873 \mathrm{~kg} / \mathrm{hari}$
\end{abstract}

Kata Kunci: kualitas air, status mutu air, indeks STORET, indeks pencemaran, Sungai Mahap

\section{Pendahuluan}

Sumber air baku Sungai Mahap dimanfaatkan oleh masyarakat Nanga Mahap untuk kebutuhan seharihari baik untuk aktivitas mandi, mencuci, juga digunakan untuk keperluan memasak dan air minum. Hal ini dilakukan masyarakat karena sampai saat ini Desa Mahap belum dialiri air bersih dari jaringan PDAM. Sungai Mahap memiliki debit sebesar 11.643,1 1t/det. Pada tahun 2007 kualitas air sungai Mahap termasuk dalam kategori baik, karena tidak ada parameter yang diuji melebihi ambang batas sesuai PP Nomor 82 Tahun 2001. Sejak terjadi perubahan tata guna lahan pada tahun 2009 diareal hulu sungai, kondisi air Sungai 
Mahap belum diketahui kualitasnya. Menurut warga setempat kualitas air di Sungai Mahap sudah tidak layak dikonsumsi, alternatif air bersih yang dapat digunakan yaitu dengan pemakaian sumur bor, namun jumlahnya tidak banyak, sehingga warga membutuhkan tersedianya jaringan air bersih [1].

Pembukaan lahan untuk perkebunan kelapa sawit dilakukan pada awal tahun 2009 dan pembukaan lahan untuk perkebunan karet pada awal tahun 2016. Hal ini mengakibatkan tingginya potensi banjir dan penurunan kualitas air [2]. Areal yang ada di Desa Nanga Mahap sebagian besar diperuntukkan untuk kebun campuran yang luasnya sekitar 890,44 Ha, kemudian untuk areal permukiman (perumahan dan berbagai fasilitas sosial-budayanya) memiliki luas sekitar $103.15 \mathrm{Ha}$, sisanya diperuntukkan untuk ladang, sawah irigasi, dan sawah tadah hujan. Selain aktivitas tersebut, pesatnya pertumbuhan penduduk di sekitar sungai Mahap menjadi sumber utama pencemaran sungai ini. Pencemaran limbah domestik akibat limbah cair dan limbah padat dari aktivitas rumah tangga ini menjadi penyebab pencemaran karena dibuang langsung tanpa melalui pengolahan.

Berdasarkan permasalahan tersebut, maka perlu dilakukan penelitian tentang gambaran kualitas air dan status mutu air serta besar beban pencemaran air sungai Mahap. Hal ini sangat penting dilakukan untuk mengukur tingkat pencemaran sungai yang terjadi saat ini, agar sungai tersebut dapat berfungsi sesuai peruntukannya dan dapat dijadikan acuan dalam pengolahan air bila air sungai ini tetap dijadikan sumber air baku untuk air minum oleh masyarakat.

\section{Metodologi Penelitian}

\section{Pengukuran debit dan pengambilan sampel air}

Pengukuran debit dilakukan dengan mengukur luas penampang sungai dan kecepatan aliran. Berdasarkan nilai luas penampang (A) dan kecepatan (V) akan didapat debit sungai (Q) dalam $\mathrm{m}^{3} /$ det. Pengukuran debit dilakukan pada musim kemarau dan musim penghujan. Untuk mengetahui titik lokasi pengukuran sampel diambil titik koordinatnya menggunakan GPS (Global Positioning System). Lokasi sungai Mahap dapat dilihat pada Gambar 1.

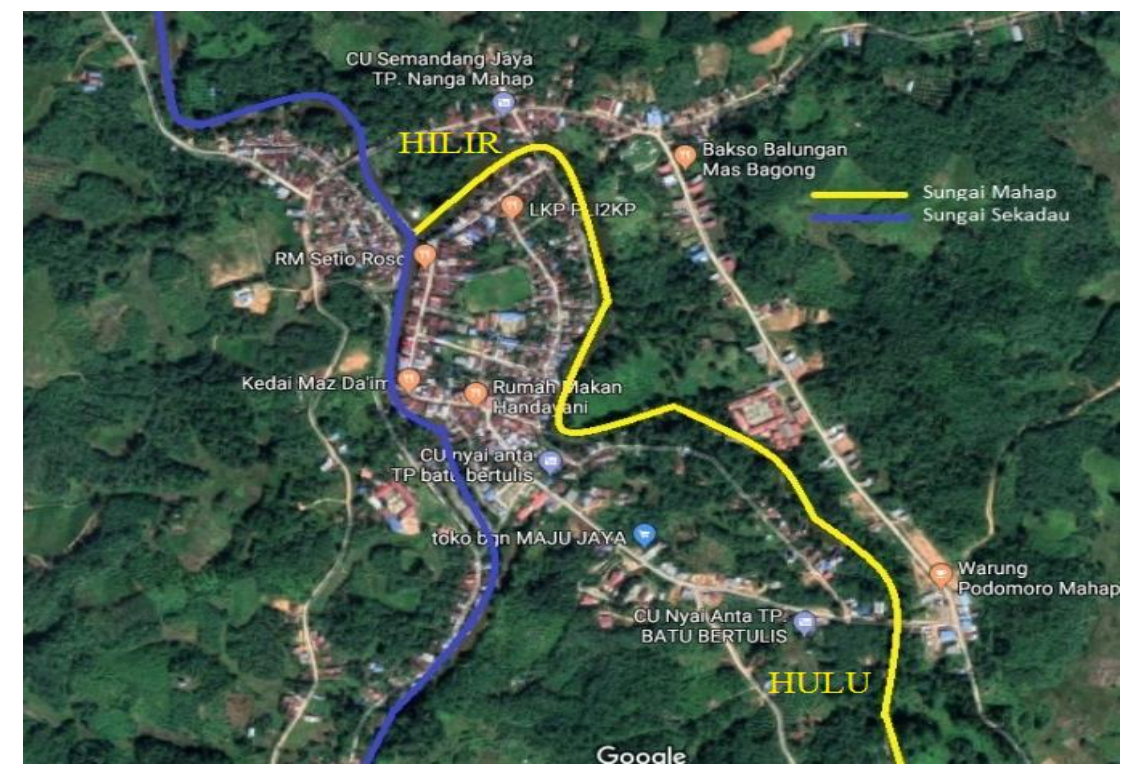

Gambar 1. Lokasi Sungai Mahap

Pengambilan sampel air di lokasi penelitian dilakukan pada aliran Sungai Nanga Mahap. Pengambilan sampel air dilakukan dengan menggunakan botol pengambil sampel ukuran $2 \mathrm{~L}$. Sampel yang diambil kemudian diawetkan dengan cara kimia yaitu dengan menambahkan asam nitrat pekat hingga $\mathrm{pH}$ sama dengan 2. Untuk pengambilan sampel air diambil sebanyak 10 sampel yaitu 5 sampel diambil pada musim kemarau yaitu pada bulan Oktober 2019 dan 5 sampel lainnya diambil pada musim hujan yaitu pada bulan November 2019. 


\section{Penentuan Status Mutu Air Menggunakan STORET}

Penentuan status mutu air menggunakan metode ini dapat dilakukan dengan memberikan skor pada tiap parameter yang diuji sesuai dengan ketentuan yang telah ditetapkan dalam Keputusan Menteri Negara Lingkungan Hidup Nomor 115 Tahun 2003. Adapun penentuan sistem penilaian ini dapat dilihat pada Tabel 1 berikut.

Tabel 1. Penentuan sistem nilai untuk menentukan status mutu air

\begin{tabular}{ccccc}
\hline $\begin{array}{c}\text { Jumlah } \\
\text { Contoh* }\end{array}$ & Nilai & \multicolumn{3}{c}{$\begin{array}{c}\text { Parameter } \\
\text { Kimia }\end{array}$} \\
\hline$<10$ & Max & -1 & -2 & -3 \\
& Min & -1 & -2 & -3 \\
& Rata-rata & -3 & -6 & -9 \\
$\geq 10$ & Max & -2 & -4 & -6 \\
& Min & -2 & -4 & -6 \\
& Rata-rata & -6 & -12 & -18 \\
\hline
\end{tabular}

Catatan: *jumlah parameter yang digunakan untuk penentuan status mutu air Sumber: Kep-MENLH No 115 Tahun 2003

Setelah semua parameter diberi skor berdasarkan ketentuan diatas, selanjutnya total skor dibandingkan dengan mutu air yang telah diklasifikasikan dalam empat kelas sebagai berikut [3]

1) Kelas A: baik sekali, skor $=0$ (memenuhi baku mutu)

2) Kelas B: baik, skor $=-1 \mathrm{~s} / \mathrm{d}-10$ (cemar ringan)

3) Kelas C: sedang, skor $=-11 \mathrm{~s} / \mathrm{d}-30$ (cemar sedang)

4) Kelas D: buruk, skor $-31 \geq$ cemar berat

\section{Penentuan Status Mutu Air Menggunakan Metode Indeks Pencemaran}

Tingkat pencemaran sungai Mahap dapat diketahui juga menggunakan metode Indeks Pencemaran. Metode ini telah diatur sesuai Keputusan Menteri Negara Lingkungan Hidup Nomor 115 Tahun 2003. Status mutu air sungai Mahap dibandingkan dengan baku mutu peruntukan air kelas I. Adapun rumus yang digunakan sebagai berikut [3] :

$$
P i j=\sqrt{\frac{\left(C_{i} / L_{i j}\right)_{2 M}+\left(C_{i} / L_{i j}\right)_{2 R}}{2}}
$$

Keterangan :

Lij : Konsentrasi parameter kualitas air yang dicantumkan dalam baku mutu peruntukan air (J)

$\mathrm{Ci} \quad$ : Konsentrasi parameter kualitas air di lapangan

Pij : Indeks pencemaran bagi peruntukan (J)

(Ci/Lij) M : Nilai, Ci/Lij maksimum

$(\mathrm{Ci} / \mathrm{Lij}) \quad$ : Nilai, Ci/Lij rata-rata

Berdasarkan Nilai Pij yang didapat pada perhitungan tersebut, kemudian dibandingkan dengan Indeks Pencemaran sepeti pada Tabel 2.

Tabel 2. Hubungan status mutu air dengan Indeks Pencemaran (IP)

\begin{tabular}{cc}
\hline Nilai IPj & Mutu Perairan \\
\hline $0-1,0$ & Kondisi baik \\
\hline $1,1-5,0$ & Cemar Ringan \\
\hline $5,0-10,0$ & Cemar Sedang \\
\hline$>10,0$ & Cemar Berat \\
\hline Sumber: Kep-MENLH No 115 Tahun 2003
\end{tabular}




\section{Perhitungan Beban Pencemaran}

Perhitungan ini dimaksudkan untuk memperkirakan beban pencemaran yang masuk kedalam sungai. Untuk mengetahui besar beban pencemaran perlu diketahui besar debit air sungai dan kadar zat pencemar yang masuk ke dalam sungai. Adapun rumus yang digunakan dalam perhitungan ini sebagai berikut [4]:

Keterangan:

$$
\mathrm{BPS}=(\mathrm{Cs}) \mathrm{j} \times \mathrm{Qs} \times \mathrm{f}
$$

$$
\begin{array}{ll}
\text { BPS } & \text { : Beban Pencemaran Sungai }(\mathrm{kg} / \mathrm{hr}) \\
(\mathrm{Cs}) \mathrm{j} & \text { : Kadar terukur sebenarnya unsur pencemar }(\mathrm{mg} / \mathrm{lt}) \\
\text { Qs } & \text { : Debit air sungai }\left(\mathrm{m}^{3} / \mathrm{hari}\right) \\
\mathrm{f} & : \text { Faktor konversi }
\end{array}
$$

\section{Hasil dan Pembahasan}

\section{Perhitungan Debit dan Hasil Uji Kualitas Air Sungai}

Sampel air sungai diambil pada lima titik dari bagian hulu hingga hilir sungai. Titik I dalam penelitian ini merupakan bagian hulu sungai. Debit air sungai tertinggi pada musim kemarau sebesar $12,11 \mathrm{~m}^{3} / \mathrm{s}$ dan pada musim hujan sebesar $23,16 \mathrm{~m}^{3} / \mathrm{s}$. Adapun lokasi pengambilan sampel dan hasil perhitungan debit sungai dapat dilihat pada Tabel 3.

Tabel 3. Lokasi pengambilan sampel air

\begin{tabular}{ccccc}
\hline Sampel & $\begin{array}{c}\text { Jarak Dari Sungai } \\
\text { (meter) }\end{array}$ & Koordinat & $\begin{array}{c}\text { Debit }\left(\mathrm{m}^{3} / \mathrm{s}\right) \\
\text { Musim } \\
\text { Kemarau }\end{array}$ & $\begin{array}{c}\text { Debit } \\
\left(\mathrm{m}^{3} / \mathrm{s}\right) \\
\text { Musim Hujan }\end{array}$ \\
\hline ST I & 50 & ${\mathrm{~S} 00^{0}}^{0} 25^{\prime} 35.4^{\prime \prime}$ & 8,17 & 10,22 \\
ST II & 43 & ${\mathrm{~S} 00^{0}}^{\circ} 25^{\prime} 35.2^{\prime \prime}$ & 12,11 & 23,16 \\
ST III & 32,5 & ${\mathrm{~S} 00^{0}}^{\prime} 25^{\prime} 33.4^{\prime \prime}$ & 7,76 & 16,61 \\
ST IV & 72 & ${\mathrm{~S} 00^{\circ}}^{2} 5^{\prime} 31.8^{\prime \prime}$ & 9,19 & 15,51 \\
ST V & 44,5 & ${\mathrm{~S} 00^{\circ}}^{2} 25^{\prime} 29.2^{\prime \prime}$ & 5,81 & 7,88 \\
\hline
\end{tabular}

Sumber: Survey (2019)

\begin{tabular}{|c|c|c|c|c|c|c|c|c|}
\hline Parameter & Alat/Metode & Satuan & ST.I & ST.II & ST.III & ST.IV & ST.V & $\begin{array}{c}\text { Baku Mutu } \\
\text { Kelas I } \\
\text { Menurut PP } \\
\text { No. } 82 \text { Tahun } \\
2001\end{array}$ \\
\hline TSS & Gravimetrik & $\mathrm{Mg} / \mathrm{L}$ & 14 & 11 & 7 & 16 & 29 & 50 \\
\hline $\mathrm{pH}$ & $\mathrm{pH}$ meter & - & 5.91 & 5.92 & 5.84 & 5.95 & 5.9 & $60-90$ \\
\hline BOD & Winkler Azide & $\mathrm{Mg} / \mathrm{L}$ & 22.49 & 20.44 & 16.19 & 24.19 & 29.71 & 2 \\
\hline COD & Closed Reflux & $\mathrm{Mg} / \mathrm{L}$ & 69.14 & 54.19 & 39.47 & 53.16 & 62.44 & 10 \\
\hline $\mathrm{DO}$ & Spectrophotometer & $\mathrm{Mg} / \mathrm{L}$ & 8.47 & 8.13 & 8.81 & 8.45 & 7.1 & 6 \\
\hline Ammonia & Spectrophotometer & $\mathrm{Mg} / \mathrm{L}$ & 0 & 0 & 0 & 0 & 0 & 0.5 \\
\hline $\mathrm{Fe}$ & ASS & $\mathrm{Mg} / \mathrm{L}$ & 0.17 & 0.27 & 0.43 & 0.03 & 0.39 & 0.3 \\
\hline
\end{tabular}

Sampel yang telah didapat kemudian di uji secara ex-situ yaitu pengujian yang dilakukan di dalam laboratorium. Pengujian sampel dilakukan di Fakultas Pertanian Laboratorium Kualitas dan Kesehatan Lahan. Hasil pengujian tersebut dapat dilihat pada Tabel 4 dan Tabel 5.

Tabel 4. Hasil analisis air Sungai Mahap pada musim kemarau

Ket:

Sumber: Hasil analisa (2019)


Tabel 5. Hasil Analisis Air Sungai Mahap Pada Musim Hujan

\begin{tabular}{|c|c|c|c|c|c|c|c|c|}
\hline Parameter & Alat/Metode & Satuan & ST.I & ST.II & ST.III & ST.IV & ST.V & $\begin{array}{c}\text { Baku Mutu } \\
\text { Kelas I } \\
\text { Menurut PP } \\
\text { No. } 82 \text { Tahun } \\
2001\end{array}$ \\
\hline TSS & Gravimetrik & $\mathrm{Mg} / \mathrm{L}$ & 10 & 17 & 19 & 14 & 20 & 50 \\
\hline $\mathrm{pH}$ & $\mathrm{pH}$ meter & - & 5.58 & 5.78 & 5.85 & 5.93 & 6.03 & $60-90$ \\
\hline BOD & Winkler Azide & $\mathrm{Mg} / \mathrm{L}$ & 19.61 & 23.92 & 30.62 & 21.19 & 32.89 & 2 \\
\hline COD & Closed Reflux & $\mathrm{Mg} / \mathrm{L}$ & 52.19 & 59.14 & 61.77 & 54.66 & 64.16 & 10 \\
\hline DO & Spectrophotometer & $\mathrm{Mg} / \mathrm{L}$ & 8.13 & 7.79 & 7.45 & 7.96 & 6.77 & 6 \\
\hline Ammonia & Spectrophotometer & $\mathrm{Mg} / \mathrm{L}$ & 0 & 0 & 0 & 0 & 0 & 0.5 \\
\hline $\mathrm{Fe}$ & ASS & $\mathrm{Mg} / \mathrm{L}$ & 0.21 & 0.03 & 0.62 & 0.2 & 0.3 & 0.3 \\
\hline
\end{tabular}

Ket: : Melebihi Baku Mutu

Berdasarkan Tabel 4. dan Tabel 5. menunjukkan bahwa air Sungai Mahap telah tercemar oleh zat organik dan besi. Hal tersebut terbukti dengan membandingkan kualitas air Sungai Mahap dengan Baku Mutu Kelas I yang mengacu pada Peraturan Pemerintah Nomor 82 tahun 2001. Sehingga dapat diketahui kelayakan air di Sungai Mahap yang hingga saat ini masih digunakan oleh masyarakat sebagai air minum.

\section{Total Suspended Solid (TSS)}

Total Suspended Solid (TSS) merupakan padatan tersuspensi penyebab terjadinya kekeruhan air. Hasil pengukuran TSS ini adalah jumlah padatan yang tersuspensi dalam satu liter air. Padatan ini terdiri atas partikel yang bobot dan ukurannya lebih kecil dari sedimen. Padatan ini dapat langsung mengendap karena tidak larut dalam air [5]. TSS disebabkan oleh erosi tanah yang ikut terbawa ke badan air dan mengandung pasir halus, jasad renik dan lumpur [6] .

Berdasarkan hasil uji pada Tabel 4 dan Tabel 5, dapat dilihat bahwa kandungan TSS dalam air masih memenuhi persyaratan baku mutu, baik pada musim hujan maupun musim kemarau. Pada musim hujan dan musim kemarau tidak menunjukkan perbedaan yang signifikan. Sebagian besar titik pengambilan sampel menunjukkan konsentrasi TSS meningkat saat musim hujan, namun belum melampaui ambang batas.

\section{Derajat Keasaman (pH)}

Pada musim kemarau maupun musim hujan, penurunan $\mathrm{pH}$ terjadi disemua titik. Namun, sebagian besar titik menunjukkan bahwa nilai $\mathrm{pH}$ cenderung mengalami penurunan pada musim kemarau dibandingkan pada musim hujan. Nilai $\mathrm{pH}$ terendah yaitu terjadi dibagian hulu sungai pada titik I sebesar 5,58. Dalam analisis ini nilai pH 5,9 masih dianggap layak dan memenuhi baku mutu. Nilai pH yang rendah dapat diakibatkan oleh jenis limbah yang mengandung asam karbonat dan asam-asam mineral bebas. Selain itu juga dapat disebabkan oleh $\mathrm{FeS}_{2}$ dalam air. Senyawa ini jika bereaksi dengan udara dan air akan membentuk $\mathrm{H}_{2} \mathrm{SO}_{4}$ dan ion $\mathrm{Fe}^{2+}$ yang larut dalam air [5].

Dibagian hulu Sungai Mahap terdapat perkebunan kelapa sawit dan karet. Selain itu disekitar rumah warga juga melakukan aktifitas pertanian. Limbah pertanian ini dapat menyebabkan penurunan pH air [7]. Penurunan nilai $\mathrm{pH}$ ini bersifat asam dan korosif, menyebabkan toksisitas logam serta proses nitrifikasi akan terhambat [8].

\section{BOD (Biochemical Oxygen Demand) dan COD (Chemical Oxygen Demand)}

BOD menunjukkan jumlah oksigen terlarut yang dibutuhkan oleh mikroba untuk memecah atau mengoksidasi bahan-bahan pencemar yang terdapat didalam suatu perairan. Umumnya, BOD mempunyai nilai lebih rendah dari COD. Hal ini dikarenakan senyawa kimia yang dapat dioksida secara kimiawi lebih besar dibandingkan dengan oksidasi secara biologis. Semakin tinggi nilai BOD dan COD maka makin tinggi tingkat pencemaran suatu badan perairan [5].

Pada musim kemarau konsentrasi BOD terendah terjadi pada titik IV yaitu sebesar 21,19 mg/L. Sedangkan konsentrasi COD juga menurun pada titik ke IV sebesar 54,66 mg/L. Pada musim hujan konsentrasi BOD dan COD terendah terjadi pada titik III yaitu secara berturut-turut sebesar $16,19 \mathrm{mg} / \mathrm{L}$ dan $39,47 \mathrm{mg} / \mathrm{L}$. Penurunan konsentrasi BOD dan COD pada titik ke III dan ke IV dikarenakan sumber pencemar 
sangat jauh dari badan sungai. Pada titik ke III lokasi rumah warga sekitar $40 \mathrm{~m}$ dari sungai dan pada titik ke IV lokasi rumah warga sekitar $70 \mathrm{~m}$ dari sungai.

Pada titik I dan titik V terdapat rumah di tepi Sungai Mahap. Hal ini dapat menjadi penyebab tingginya BOD dan COD pada titik tersebut karena pembuangan limbah domestik dari limbah rumah tangga yang langsung ke badan sungai. Masyarakat masih membuang sampah padat di pinggir sungai. Sehingga banyak penumpukan sampah dipinggir sungai dan beberapa sampah hanyut pada bila musim penghujan.

Tingginya BOD dan COD di titik I juga bersumber dari perendaman karet di sungai. Perendaman karet dapat menyebabkan kandungan COD, $\mathrm{BOD}_{5}$, TSS, TDS dan warna dalam air sungai meningkat [9].

Konsentrasi zat pencemar BOD dan COD tertinggi terjadi pada titik V (hilir sungai) karena limbah yang masuk ke sungai tidak hanya berasal dari rumah penduduk tetapi juga berasal dari aktivitas pasar. Limbah dari pasar mengandung banyak bahan organik. Limbah domestik seperti aktivitas mandi, cuci, kakus, kebun dan persawahan dapat mengakibatkan masuknya bahan organik sehingga menurunkan kualitas air. Limbah dari rumah tangga ini jika langsung dibuang ke sungai tanpa adanya pengolahan maka akan meningkatkan kandungan BOD dan COD pada badan perairan tersebut [10].

Konsentrasi BOD dan COD di Sungai Mahap baik pada musim hujan maupun pada musim kemarau selalu melebihi baku mutu yang telah ditetapkan, namun besarnya masih tergolong lemah. Terdapat berbagai jenis tipe limbah berdasarkan beban konsentrasi polutan organik [11]. Jenis air limbah dengan kandungan BOD kurang dari $200 \mathrm{mg} / \mathrm{l}$ dan COD kurang dari $400 \mathrm{mg} / \mathrm{l}$ termasuk dalam kategori lemah. Kenaikan kandungan BOD dan COD pada tiap titik dapat terjadi karena selama perjalanannya aliran air sungai ini banyak menerima limbah buangan dari hulu hingga hilir.

\section{DO (Dissolve Oxygen)}

Konsentrasi DO di Sungai Mahap belum melampaui ambang batas yang telah ditetapkan. Nilai tersebut masih tergolong memenuhi peruntukkan air sesuai PP Nomor 82 tahun 2001. Pada titik V terjadi penurunan konsentrasi DO, hal ini dapat disebabkan limbah domestik dari rumah masyarakat yang masuk ke badan perairan karena berada di tepian sungai. Oksigen yang terlarut dapat juga menurun seiring tingginya padatan terlarut (TSS). Pada titik V terjadi peningkatan TSS sehingga terjadi penurunan konsentrasi DO sebesar 6,77 pada musim kemarau dan $7,1 \mathrm{mg} / \mathrm{L}$ pada musim hujan.

Besarnya konsentrasi DO dalam air ini dapat dipengaruhi oleh beberapa faktor seperti kandungan TSS, salinitas, temperatur, degradasi bahan organik, laju fotosintesis serta tekanan atmosfer [12]. Kandungan DO dalam perairan berbanding terbalik dengan suhu dan ketinggian namun berbanding lurus dengan tekanan atmosfer. Semakin turun kadar oksigen terlarut dalam perairan maka semakin turun tekanan, serta jika suhu dan ketinggian meningkat maka kadar DO semakin menurun [13].

\section{Ammonia $\left(\mathrm{NH}_{3}\right)$}

Hasil uji kandungan ammonia pada perairan Sungai Mahap baik pada musim hujan maupun musim kemarau, menunjukkan bahwa tidak ada kandungan ammonia pada air sungai tersebut. Kandungan ammonia biasanya meningkat apabila tercemar limbah domestik dan pertanian karena ammonia terdapat dalam pupuk urea dan deterjen. Namun kandungan ammonia dapat menurun jika suatu badan perairan mengandung kandungan oksigen terlarut (DO) yang tinggi. Sehingga kandungan ammonia biasanya tidak ditemukan pada badan perairan yang memiliki cukup pasokan oksigen dalam air tersebut [14]. Hasil pengukuran menunjukkan bahwa kandungan DO pada air Sungai Mahap relatif tinggi dan dalam kondisi baik untuk badan perairan. Hal inilah yang menyebabkan kandungan ammonia pada sungai tersebut rendah bahkan hampir tidak ada. Selain itu, rendahnya kedalaman air sungai juga dapat menurunkan kandungan ammonia [15].

Besi (Fe)

Berdasarkan hasil diatas dapat dilihat bahwa kandungan besi pada perairan Sungai Mahap meningkat pada titik III dan titik V baik pada musim hujan maupun pada musim kemarau. Sedangkan pada titik lainnya kandungan besi dalam air menurun. Besi dapat berasal dari pupuk, pestisida, korosi pipa-pipa air dan pada umumnya kandungan besi di air ini memang terdapat dialam karena kontak langsung antara air tersebut dengan tanah. Kandungan besi yang berlebih dalam air akan menimbulkan rasa yang tidak enak pada air minum, menambah kekeruhan dan menimbulkan endapan [16].

Kecamatan Nanga Mahap memiliki jenis tanah PMK (Podsolik Merah Kuning), dan Podsol, serta alluvial [2]. Tanah ini terbentuk dari hasil pelapukan batuan induk yang berumur (miosen). Jenis tanah ini sangat dipengaruhi oleh topografi, umur, iklim dan vegetasi. Kandungan besi yang tinggi di dalam air dapat 
diakibatkan oleh sumber alami tanah podsolik ini. Tanah ini juga bersifat masam sehingga dapat mempengaruhi kualitas perairan [17].

Wilayah desa Nanga Mahap sebagian besar diperuntukkan untuk kebun campuran, permukiman sisanya diperuntukkan untuk ladang, sawah irigasi, dan sawah tadah hujan [2]. Aktivitas ini juga dapat menjadi sumber tingginya kandungan besi dalam air akibat aktivitas pemupukan tanaman.

\section{Penentuan Status Mutu Air Sungai Mahap dengan Metode STORET}

Penentuan status mutu air menggunakan metode storet dimaksudkan dengan tujuan untuk melihat mutu suatu sistem akuatik [18]. Berdasarkan hasil uji kualitas air secara periodik dapat diketahui nilai minimum dan maksimum kandungan dalam air Sungai Mahap. Hasil uji kualitas air tersebut kemudian dibandingkan dengan baku mutu yang sesuai dengan peruntukan air. Adapun hasilnya dapat dilihat pada tabel Tabel 6 berikut.

Tabel 6. Status Mutu Air Sungai Mahap Menggunakan Metode STORET

\begin{tabular}{ccccccccc}
\hline Titik & Skor & Kelas I & Skor & Kelas II & Skor & Kelas III & Skor & Kelas IV \\
\hline ST I & -28 & Cemar sedang & -28 & Cemar sedang & -28 & Cemar sedang & -18 & Cemar sedang \\
ST II & -28 & Cemar sedang & -28 & Cemar sedang & -28 & Cemar sedang & -18 & Cemar sedang \\
ST III & -40 & Cemar berat & -30 & Cemar sedang & -30 & Cemar sedang & -20 & Cemar sedang \\
ST IV & -20 & Cemar sedang & -20 & Cemar sedang & -20 & Cemar sedang & -20 & Cemar sedang \\
ST V & -30 & Cemar sedang & -20 & Cemar sedang & -20 & Cemar sedang & -20 & Cemar sedang \\
\hline
\end{tabular}

Sumber: Hasil analisa (2019)

Berdasarkan tabel diatas dapat disimpulkan bahwa status mutu air Sungai Mahap telah tercemar sedang hingga berat. Status mutu air tercemar sedang hingga berat bila diperuntukkan sesuai kelas I yaitu sebagai air baku air minum. Bila diperuntukkan untuk kelas II sebagai sarana rekreasi air, kelas III untuk budi daya ikan tawar dan peternakan, dan kelas IV untuk pertanaman, Sungai Mahap tergolong tercemar sedang. Untuk lebih jelasnya dapat dilihat pada Gambar 2.

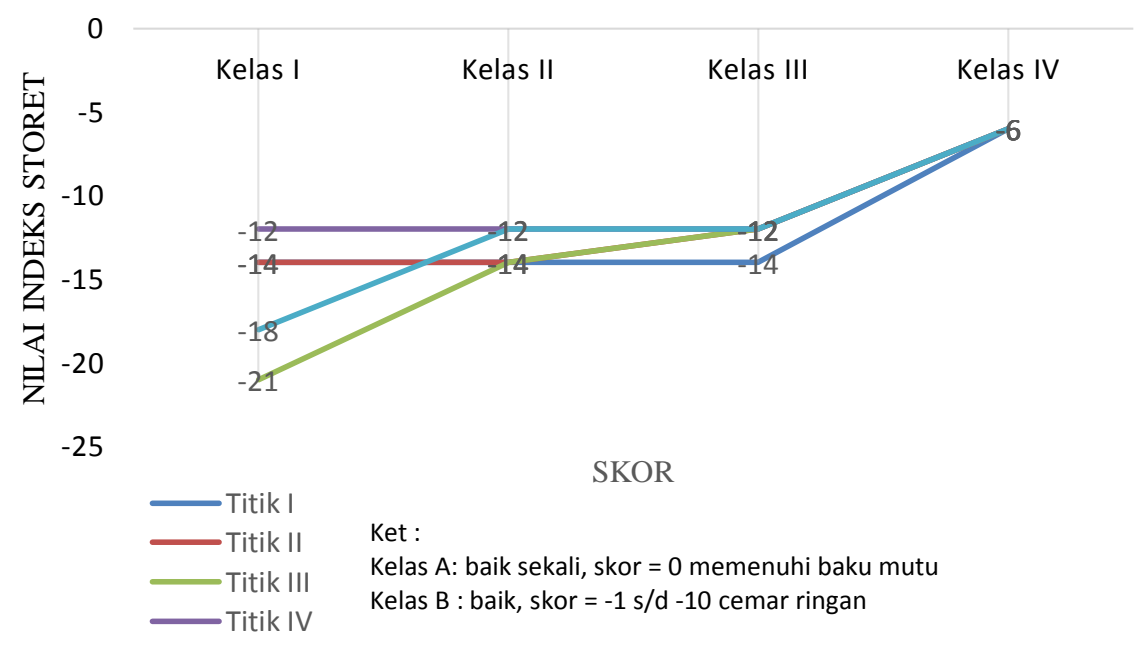

Gambar 2. Status mutu air Sungai Mahap Berdasarkan Metode STORET

\section{Penentuan Status Mutu Air Sungai Mahap dengan Indeks Pencemaran}

Metode Indeks Pencemaran lebih unggul jika memakai data tunggal dibandingkan metode STORET yang memerlukan data time series, namun hanya mempresentasikan status mutu air pada saat itu saja tidak dalam periode tertentu [19]. Indeks pencemaran ini dapat digunakan untuk menentukan tingkat pencemaran terhadap parameter kualitas air yang diizinkan untuk suatu peruntukan dan dapat dikembangkan untuk beberapa peruntukan lainnya seluruh bagian badan air atau sebagian dari suatu badan air. Hasil yang didapat dari metode ini dapat dijadikan acuan untuk pengambilan keputusan agar dapat dilakukan pengelolaan dan pengolahan untuk memperbaiki kualitas air sesuai dengan peruntukannya jika terjadi penurunan akibat kehadiran senyawa pencemar tersebut [14]. 
Tabel 7. Status mutu air Sungai Mahap dengan Metode Indeks Pencemaran

\begin{tabular}{ccc}
\hline Titik Pengambilan & Skor IP & Status Mutu \\
\hline I & 8.86 & Tercemar sedang \\
II & 8.91 & Tercemar sedang \\
III & 9.81 & Tercemar sedang \\
IV & 8.93 & Tercemar sedang \\
V & 11.01 & Tercemar berat \\
\hline
\end{tabular}

Sumber: Hasil analisa (2019)

Tabel 7 menunjukkan bahwa Sungai Mahap telah tercemar sedang hingga berat bila diperuntukkan untuk air minu (Kelas I). Pada titik V status mutu air tercemar berat. Lokasi ini merupakan bagian hilir sungai dengan padat penduduk. Sehingga pencemaran lebih tinggi terjadi pada titik ini. Limbah domestik dari aktifitas rumah tangga baik limbah cair maupun limbah padat dibuang ke sungai.

\section{Beban Pencemaran Sungai Mahap}

Beban pencemaran sungai dihitung berdasarkan besarnya konsentrasi zat pencemar dan debit sungai. Pada penelitian ini beban pencemaran sungai dihitung berdasarkan debit pada musim kemarau dan musim penghujan. Hasil beban pencemaran Sungai Mahap dapat dilihat pada Tabel 8 dan Tabel 9.

Tabel 8. Beban Pencemaran Sungai Mahap Pada musim Kemarau

\begin{tabular}{|c|c|c|c|c|c|c|c|c|c|c|c|}
\hline \multirow[t]{2}{*}{ Titik } & \multirow[t]{2}{*}{ TSS } & \multirow[t]{2}{*}{ BOD } & \multirow[t]{2}{*}{ COD } & \multirow[t]{2}{*}{$\mathrm{Fe}$} & \multirow{2}{*}{$\begin{array}{l}\text { Debit } \\
\left(\mathrm{m}^{3} / \mathrm{s}\right)\end{array}$} & \multirow{2}{*}{$\begin{array}{l}\text { Faktor } \\
\text { Koreksi }\end{array}$} & \multicolumn{4}{|c|}{ Beban Pencemaran (Kg/ Hari) } & \multirow{2}{*}{$\begin{array}{c}\text { Total } \\
\text { (Kg/Hari) }\end{array}$} \\
\hline & & & & & & & TSS & BOD & COD & $\mathrm{Fe}$ & \\
\hline \multirow[t]{2}{*}{ I } & 10 & 19.61 & 52.19 & 0.21 & 8.17 & 86.4 & & & & & \\
\hline & & & & & & & 7,059 & 13,842 & 36,840 & 148 & 57,890 \\
\hline \multirow[t]{2}{*}{ II } & 17 & 23.92 & 59.14 & 0.03 & 12.11 & 86.4 & & & & & \\
\hline & & & & & & & 17,787 & 25,028 & 61,878 & 31 & 104,725 \\
\hline \multirow[t]{2}{*}{ III } & 19 & 30.62 & 61.77 & 0.62 & 7.70 & 86.4 & & & & & \\
\hline & & & & & & & 12,640 & 20,371 & 41,094 & 412 & 74,518 \\
\hline \multirow[t]{2}{*}{ IV } & 14 & 21.19 & 54.66 & 0.2 & 9.19 & 86.4 & & & & & \\
\hline & & & & & & & 11,116 & 16,825 & 43,401 & 159 & 71,501 \\
\hline \multirow[t]{2}{*}{$\mathrm{V}$} & 20 & 32.89 & 64.16 & 0.3 & 5.81 & 86.4 & & & & & \\
\hline & & & & & & & 10,040 & 16,510 & 32,207 & 151 & 58,908 \\
\hline
\end{tabular}

Sumber: Hasil analisa (2019)

Tabel 9. Beban Pencemaran Sungai Mahap Pada musim Hujan

\begin{tabular}{|c|c|c|c|c|c|c|c|c|c|c|c|}
\hline \multirow[t]{2}{*}{ Titik } & \multirow[t]{2}{*}{ TSS } & \multirow[t]{2}{*}{ BOD } & \multirow[t]{2}{*}{ COD } & \multirow[t]{2}{*}{$\mathrm{Fe}$} & \multirow{2}{*}{$\begin{array}{l}\text { Debit } \\
\left(\mathrm{m}^{3} / \mathrm{s}\right)\end{array}$} & \multirow{2}{*}{$\begin{array}{l}\text { Faktor } \\
\text { Koreksi }\end{array}$} & \multicolumn{4}{|c|}{ Beban Pencemaran (Kg/ Hari) } & \multirow{2}{*}{$\begin{array}{c}\text { Total } \\
(\text { Kg/Hari) }\end{array}$} \\
\hline & & & & & & & TSS & BOD & COD & $\mathrm{Fe}$ & \\
\hline \multirow[t]{2}{*}{ I } & 14 & 22.49 & 69.14 & 0.17 & 10.22 & 86.4 & & & & & \\
\hline & & & & & & & 12,367 & 19,867 & 61,076 & 150 & 93,460 \\
\hline \multirow[t]{2}{*}{ II } & 11 & 20.44 & 54.19 & 0.27 & 23.16 & 86.4 & & & & & \\
\hline & & & & & & & 22,009 & 40,897 & 108,426 & 540 & 171,873 \\
\hline \multirow[t]{2}{*}{ III } & 7 & 16.19 & 39.47 & 0.43 & 16.61 & 86.4 & & & & & \\
\hline & & & & & & & 10,044 & 23,231 & 56,636 & 617 & 90,529 \\
\hline \multirow[t]{2}{*}{ IV } & 16 & 24.19 & 53.16 & 0.03 & 15.51 & 86.4 & & & & & \\
\hline & & & & & & & 21,444 & 32,421 & 71,248 & 40 & 125,154 \\
\hline \multirow[t]{2}{*}{$\mathrm{V}$} & 19 & 29.71 & 62.44 & 0.39 & 7.88 & 86.4 & & & & & \\
\hline & & & & & & & 12,937 & 20,230 & 42,516 & 266 & 75,949 \\
\hline
\end{tabular}

Sumber: Hasil analisa (2019)

Beban pencemaran sungai tertinggi pada musim hujan dan musim kemarau terjadi pada titik II yaitu pada sebesar $104.725 \mathrm{~kg} / \mathrm{hari}$. Sedangkan pada musim hujan sebesar $171.873 \mathrm{~kg} / \mathrm{hari}$. Pada parameter yang melebihi baku mutu seperti BOD, COD dan Fe, dapat diketahui berdasarkan hasil perhitungan bahwa beban pencemaran BOD tertinggi pada musim kemarau sebesar $25.028 \mathrm{~kg} / \mathrm{hari}$, COD sebesar $61.878 \mathrm{~kg} / \mathrm{hari}$ dan besi sebesar $412 \mathrm{~kg} / \mathrm{hari}$. Pada musim hujan, beban pencemaran tertinggi sebesar $40.897 \mathrm{~kg} / \mathrm{hari}$, COD sebesar $108.426 \mathrm{~kg} / \mathrm{hari}$ dan besi sebesar $617 \mathrm{~kg} / \mathrm{hari}$. 
Debit aliran dan kadar unsur zat pencemar mempengaruhi tinggi rendahnya beban pencemaran. Beban pencemaran sungai berbanding lurus dengan debit aliran dan unsur zat pencemar. Semakin tinggi nilai keduanya maka semakin tinggi pula beban pencemaran sungai tersebut [20]. Debit yang tinggi pada titik II menyebabkan beban pencemaran sungai yang masuk pada titik tersebut menjadi lebih besar.

\section{Kesimpulan}

Sungai Mahap telah tercemar sedang hingga berat bila diperuntukkan untuk kelas I. Sebaiknya air sungai Mahap diolah terlebih dahulu sebelum dikonsumsi. Sistem pengolahan yang direkomendasikan adalah pengolahan lengkap dengan proses koagulasi, flokulasi, sedimentasi, filtrasi, dan desinfeksi. Pengolahan air ini bertujuan agar air yang dikonsumsi aman bagi kesehatan masyarakat sekitar, karena dapat menurunkan konsentrasi zat pencemar yang telah melampaui baku mutu yang telah ditetapkan. Selain itu proses desinfeksi direkomendasikan untuk pencegahan pencemaran oleh bakteri E.coli dalam air. Pemerintah dapat merencanakan sistem penyediaan air minum ini demi mendukung tercapainya Sustainable Development Goals (SDGs) terkait penyediaan air bersih dan sanitasi, pada daerah yang belum terlayani fasilitas air bersih seperti di desa Nanga Mahap dan beberapa desa terjangkau di Kabupaten Sekadau.

\section{Daftar Pustaka}

[1] Kiwi, ”Warga Nanga Mahap Harap Pasokan Air Bersih”, Suara Pemred, 2017

[2] Akbar, Rezky, "Penanganan Bencana Banjir Berdasarkan Kearifan Lokal Pada Masyarakat Kecamatan Nanga Mahap Kabupaten Sekadau," Skripsi, Jurusan Teknik Lingkungan Universitas Tanjungpura, Pontianak, 2019.

[3] Kementerian Lingkungan Hidup, "Keputusan Menteri Negara Lingkungan Hidup Nomor 115 tahun 2003 tentang Pedoman Penentuan Status Mutu air," Jakarta, 2003.

[4] Marganof, "Model Pengendalian Pencemaran Perairan di Danau Maninjau Sumatra Barat," Kampus IPB, Bogor, 2007.

[5] Manik, K. Eddy Sontang, Pengelolaan Lingkungan Hidup, Jambatan, Jakarta, 2009.

[6] Nicola, F, "Hubungan Antara Konduktivitas, TDS (Total Dissolved Solid) dan TSS (Total Suspended Solid) dengan Kadar Fe2+ dan Fe Total Pada Air Sumur Gali,” Universitas Jember, 2015.

[7] Ringgo, Siringgo R., Jhonny, dan Rahayu, Dian Jati. "Kajian Beban Pencemaran Beberapa Anak Sungai Dan Saluran Drainase Yang Bermuara Ke Sungai Kapuas Di Kota Pontianak (Studi Kasus: Kelurahan Sungai Jawi Luar dan Kelurahan Sungai Beliung Kecamatan Pontianak Barat), Jurnal Teknologi Lingkungan Lahan Basah, Vol 2. No 1, 2014.

[8] Yogafani, Ekha, Pengaruh Aktifitas Warga di Sempadan Sungai terhadap Kualitas Air Sungai Winongo. Jurnal Sains Teknologi dan Lingkungan Vol.7.No.1, 2015

[9] Suwandi, Riskawanti., Irawan, Chairul dan Rachmadi, Andri Taruna. Pengolahan Limbah Perendaman Karet Rakyat dengan Metode Koagulasi Dan Flokulasi Menggunakan Aluminium Sulfat, Ferri Klorida, Dan Poli Aluminium Klorida (PAC). Jurnal Biopropal Industri. Vol7. No1, 2016

[10] Sheftiana, Sarah Ulfah., Samriningsih, Anik., dan Nugraha, Winardi Dwi. "Penentuan Status Mutu Air Sungai Berdasarkan Metode Indeks Pencemaran Sebagai Pengendalian Kualitas Lingkungan (Studi Kasus: Sungai Gelis, Kabupaten Kudus, Jawa Tengah),” Jurnal Teknik Lingkungan, Vol 6. No.1, 2017.

[11] Mara, Duncan. Domestic Wastewater Treatment Developing Countries. Published by Earthscan in The UK and USA in 2004. 2004

[12] Wardhana, Wisnu. Dampak pencemaran lingkungan.Yogyakarta. Penerbit Andi. 2001.

[13] Effendi, H, “Telaah Kualitas Air: Bagi Pengelolaan Sumber Daya dan Lingkungan,” 2003.

[14] Asuhadi, Sunarwan., dan Abdul, Manan. Status Mutu Air Pelabuhan Panggulubelo Berdasarkan Indeks Storet dan Indeks Pencemaran," Jurnal Kelautan Nasional, Vol 13. No.2a, 2018.

[15] Welch, P. S. Limnology. Second edition. McGraw Hill International Book Company. New York, 1952.

[16] Makhmudah, N, "Penyisihan Besi-Mangan, Kekeruhan, dan Warna Menggunakan Saringan Pasir Lambat Dua Tingkat Pada Kondisi Aliran Tak Jenuh Studi Kasus: Air Sungai Cikapundung,” Jurnal Teknik Lingkungan, Vol 16. No 2, 2010.

[17] Rezagama, Arya, A. Tamlika, "Identifikasi Pencemar Waduk Manggar Kota Balikpapan," Jurnal Pengembangan Kota, Vol 4. No. 1, 2016. 
[18] Waluko, AF, "Penentuan Status Mutu Air Dengan Metode Storet di Danau Sentani Jayapura Propinsi Papua," Berita Biologi, Vol 10. No 3, 2010.

[19] Romdania, Y., Herison, A., Susilo, G. E., \& Novilyansa, E, "Kajian Penggunaan Metode IP, STORET, Dan CCME WQI Dalam Menentukan Status Kualitas Air Spatial," Journal of Geographical Studies, 18(1), $1-13,2018$.

[20] Yuliastuti, Etik. "Kajian Kualitas Air Sungai Ngringo Karanganyar dalam Upaya Pengendalian Pencemaran Air", Tesis (Semarang: Universitas Diponegoro Program Magister Ilmu Lingkungan), 2011 